\title{
Heterologous expression and characterization of a malathion-hydrolyzing carboxylesterase from a thermophilic bacterium, Alicyclobacillus tengchongensis
}

\author{
Zhenrong Xie $\cdot$ Bo Xu $\cdot$ Junmei Ding $\cdot$ \\ Lingyun Liu $\cdot$ Xuelin Zhang $\cdot$ Junjun Li $\cdot$ \\ Zunxi Huang
}

Received: 16 February 2013/Accepted: 20 March 2013/Published online: 26 June 2013

(C) The Author(s) 2013. This article is published with open access at Springerlink.com

\begin{abstract}
A carboxylesterase gene from thermophilic bacterium, Alicyclobacillus tengchongensis, was cloned and expressed in Escherichia coli BL21 (DE3). The gene coded for a 513 amino acid protein with a calculated molecular mass of $57.82 \mathrm{kDa}$. The deduced amino acid sequence had structural features highly conserved among serine hydrolases, including Ser204, Glu325, and His415 as a catalytic triad, as well as type-B carboxylesterase serine active site (FGGDPENITIGGQSAG) and type-B carboxylesterase signature 2 (EDCLYLNIWTP).
\end{abstract}

Z. Xie $(\bowtie) \cdot$ B. Xu · J. Ding · L. Liu · X. Zhang .

J. Li $\cdot$ Z. Huang

College of Life Sciences, Yunnan Normal University, Kunming, Yunnan 650500, People's Republic of China e-mail: xiezhenrong2006kycg@126.com

B. $\mathrm{Xu}$

e-mail: xubo128028@163.com

J. Ding

e-mail:djm3417@yahoo.cn

L. Liu

e-mail: eileen7802@163.com

X. Zhang

e-mail: zxl_ocean@126.com

J. Li

e-mail: 1979ljsx@163.com

B. Xu · J. Ding $\cdot$ J. Li $\cdot$ Z. Huang $(\bowtie)$

Engineering Research Center of Sustainable Development and Utilization of Biomass Energy, Ministry of Education, Kunming, Yunnan 650500, People's Republic of China e-mail: huangzunxi@163.com
The purified enzyme exhibited optimum activity with $\beta$-naphthyl acetate at $60{ }^{\circ} \mathrm{C}$ and $\mathrm{pH} 7$ as well as stability at $25^{\circ} \mathrm{C}$ and $\mathrm{pH}$ 7. One unit of the enzyme hydrolyzed $5 \mathrm{mg}$ malathion $\mathrm{l}^{-1}$ by $50 \%$ within $25 \mathrm{~min}$ and $89 \%$ within $100 \mathrm{~min}$. The enzyme strongly degraded malathion and has a potential use for the detoxification of malathion residues.

Keywords Carboxylesterase - Degradation · Expression $\cdot$ Malathion

\section{Introduction}

Malathion [S-(1,2-dicarbethoxyethyl)-O,O-dimethyldithiophosphate; also known as carbophos, maldison, and mercaptothion] is a non-systemic, wide-spectrum organophosphorus pesticide used for public health, residential, and agricultural purposes. However, malathion is toxic to living organisms including humans because it is easily absorbed by the gastrointestinal tract, skin, mucous membranes, and lungs (Inderjeet et al. 1997; Kumar et al. 2010). Malathion targets the central nervous and immune system, thereby affecting many organs and functions. These findings reveal that malathion is potentially harmful to human health and the ecosystem. Therefore, efficient strategies must be urgently developed to solve these problems caused by malathion residues.

Biodegradation is an important environment biotechnology for the treatment of organic pollutants. 
One treatment strategy is the use of some key enzymes to break down pesticide residues. Carboxylesterases (carboxylic ester hydrolase; EC 3.1.1.1) can degrade organophosphorus pesticides, carbamates, pyrethoid insecticides, and organic chloride pesticides (Vontas et al. 2000; Zhang et al. 2004; Barata et al. 2004; Nishi et al. 2006). Carboxylesterases can also catalyze the degradation of malathion to the detoxication products monoacid and diacid derivatives (Yoshii et al. 2007a).

Some carboxylesterases from animals, plants, and insects have been purified, characterized and used to degrade malathion (Miller et al. 1999; Yoshii et al. 2007b; Cao et al. 2008). Several malathion-degrading strains have been isolated, and degradation studies have also been carried out (Foster and Bia 2004; Hashmi et al. 2004; Goda et al. 2010). Microbial carboxylesterase genes have been cloned and expressed as well (Prim et al. 2001; Ewis et al. 2004), but studies on the use of microbial carboxylesterases for pesticide degradation are limited.

Next-generation sequencing technologies enable high-throughput functional genomic research. For example, a novel xylanase from the genome sequence of Thermonanarobacterium saccharolyticum NTOU1 (Hung et al. 2011) and pectate lyase from the genome sequence of Bacillus sp. I4 (Zhou et al. 2012) have been cloned and expressed in Escherichia coli BL21 (DE3). However, a carboxylesterase from a thermophilic bacterium, A. tengchongensis, for malathion degradation has not yet been heterologously expressed. In the present study, we cloned and expressed a carboxylesterase (D1CarE5) from the genomic DNA of this thermophile whose whole genome has been sequenced with a Solexa Genome Analyzer. We have thus gained insight into the characteristics of recombinant D1CarE5 and its malathion-degradation potential.

\section{Materials and methods}

Strains and reagents

Alicyclobacillus tengchongensis was isolated from a hot spring in Tengchong, Yunnan, China. Escherichia coli BL21 (DE3) and the expression vector, pET28a(+), were from Novagen. Malathion (99\% purity) was from Sigma. Taq DNA polymerase, Pyrobest NDA polymerase, dNTPs, BamHI and XhoI were from
TaKaRa. Genomic DNA isolation, DNA purification, and plasmid isolation kits were from Tiangen. All other chemicals were analytical grade.

Sequence analyses

Genomic DNA of the thermophilic A. tengchongensis strain was extracted using a Tiangen genomic DNA isolation kit from cells grown overnight at $50{ }^{\circ} \mathrm{C}$. Genome sequencing was performed by the Beijing Genomics Institute (Guangzhou, China) using a Solexa Genome Analyzer, and a partial genomic sequence was obtained. The full-length carboxylesterase gene D1CarE5 was revealed based on the prediction of ORFs from a partial genomic sequence by the GeneMark.hmm online tool (version 2.8; http://exon.gatech.edu/Gene Mark/gmhmm2_prok.cgi). The signal peptide in the amino acid sequence (D1CarE5) deduced from D1CarE5 was predicted using SignalP (http://www.cbs.dtu.dk/ services/SignalP/). The identity values of the protein sequences were obtained from the online BLASTP program (http://www.ncbi.nlm.nih.gov/BLAST/). Defined structural features were analyzed using the Prosite Database at ExPASy (http://au.expasy.org/prosite/). Phylogenetic tree was constructed using MEGA 4.1 software by neighbor-joining method. Other sequence analyses were performed using BioXM 2.6 software (Nanjing Agricultural University, Nanjing, China).

\section{Expression of D1CarE5 gene}

The nucleotide sequence of putative D1CarE5 ORF from A. tengchongensis was cloned by PCR. The forward primer with a BamHI restriction site was $5^{\prime}$ CGCGGATCCATGCAAAGCATGCTGCGG- $3^{\prime}$, and the reverse primer with a XhoI restriction site was $5^{\prime}$ CCGCTCGAGGAAAATGTACTGTTTTTGCTTAA AG- $3^{\prime}$. The PCR conditions were as follows: 5 min of denaturation at $94{ }^{\circ} \mathrm{C}, 30$ cycles of denaturing at $94{ }^{\circ} \mathrm{C}$ for $45 \mathrm{~s}$, primer annealing at $50{ }^{\circ} \mathrm{C}$ for $30 \mathrm{~s}$, extension at $72{ }^{\circ} \mathrm{C}$ for $1 \mathrm{~min}$, and a final extension at $72{ }^{\circ} \mathrm{C}$ for $5 \mathrm{~min}$. The PCR products were purified using a PCR purification kit (TianGen). The pET28a (+) vector and PCR products were completely digested with BamHI and XhoI, respectively. The recombinant plasmid was transformed into $E$. coli BL21 (DE3) for protein expression. The transformed strains were grown in LB medium containing $50 \mu \mathrm{g}$ 


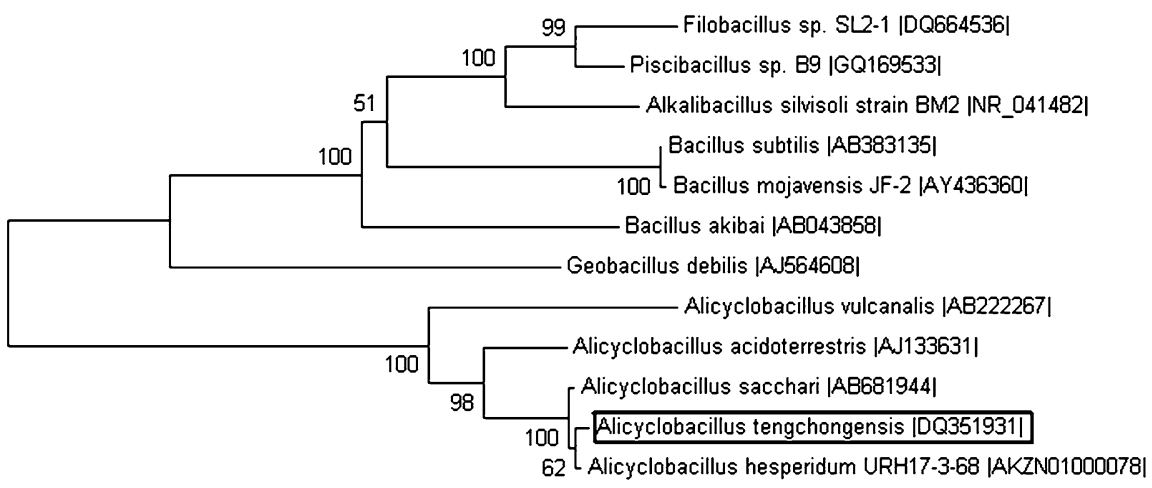

$\stackrel{\longmapsto}{0.01}$

Fig. 1 The 16S rDNA-based neighbor-joining tree showing the phylogenetic position of Alicyclobacillus tengchongensis strain. Boostrap values ( $n=1,000$ replicates) are reported as percentages (only values above $50 \%$ are given). Sequences were

kanamycin $\mathrm{ml}^{-1}$ at $37{ }^{\circ} \mathrm{C}$ until the $\mathrm{OD}_{600}$ reached 0.3 . Protein expression was induced by adding IPTG to $0.05 \mathrm{mM}$, the culture was shaken for $20 \mathrm{~h}$ at $20^{\circ} \mathrm{C}$, and the cells were harvested by centrifugation.

\section{Purification of recombinant D1CarE5}

Cells were harvested by centrifugation at $10,000 \times g$ for 10 min at $4{ }^{\circ} \mathrm{C}$, washed with sterile distilled $\mathrm{H}_{2} \mathrm{O}$, and resuspended in sterilized ice-cold buffer A $(20 \mathrm{mM}$ Tris/ $\mathrm{HCl}$ and $0.5 \mathrm{M} \mathrm{NaCl} ; \mathrm{pH} 7.2)$. The cells were disrupted by sonication $(7 \mathrm{~s}, 150 \mathrm{~W}$ ) on ice for several times and centrifuged at $10,000 \times g$ for $10 \mathrm{~min}$ at $4{ }^{\circ} \mathrm{C}$. The supernatant was applied to a $\mathrm{Ni}^{2+}$-NTA agarose gel column for purification with a linear imidazole gradient of 20-500 $\mathrm{mM}$ in buffer $\mathrm{A}$.

The purified protein was detected by PAGE using a $5 \%(\mathrm{v} / \mathrm{v})$ stacking gel and a $12 \%(\mathrm{v} / \mathrm{v})$ resolving gel. Protein concentration was determined by Bradford's method using bovine serum albumin as the standard.

\section{Carboxylesterase assay}

D1CarE5 activity was assayed with $\beta$-naphthyl acetate as substrate by the method of Van (Van 1962). Absorbance was measured at $554 \mathrm{~nm}$ for $\beta$-naphthyl acetate, and one unit of activity $(\mathrm{U})$ was defined as the amount of enzyme that produced $1 \mu \mathrm{mol} \beta$-naphthol from the substrate per $\min$. The $K_{\mathrm{m}}$ and $V_{\max }$ values for the purified D1CarE5 were determined using $0.1-0.95 \mathrm{mM} \beta$-naphthyl acetate obtained from GenBank (http://www.ncbi.nlm.nih.gov). The scale bar represents the number of changes per nucleotide position. Accession numbers are given at the end of each species name. The strain in the present study is shown in black bars

as substrate at $60{ }^{\circ} \mathrm{C}$ in potassium phosphate buffer $(\mathrm{pH} 7)$.

Nucleotide sequence accession number

The nucleotide sequences for 16S rDNA and D1CarE5 of the thermophilic A. tengchongensis strain were deposited in GenBank under accession numbers DQ351931 and JX101458, respectively.

Pesticide degradation and analytical methods

Malathion degradation by D1CarE5 was determined by the method of Leng and Qiao (1986) with some modifications. Malathion was dissolved in acetone $(100 \mathrm{mg} / \mathrm{l})$ and $300 \mu \mathrm{l}$ was mixed with $4.7 \mathrm{ml} 25 \mathrm{mM}$ potassium phosphate buffer $(\mathrm{pH} \mathrm{7})$ and $1 \mathrm{ml}$ diluted enzyme $(1 \mathrm{U} / \mathrm{ml})$. The total reaction volume was $6 \mathrm{ml}$. Malathion solution without enzyme served as a control. The mixtures were incubated at $37^{\circ} \mathrm{C}, 0.5 \mathrm{ml}$ samples were collected at intervals, and $0.5 \mathrm{ml} n$-hexane was added to extract the product. The supernatant was collected by centrifugation and dried over anhydrous $\mathrm{Na}_{2} \mathrm{SO}_{4}$. The residual malathion was analyzed using a GC/MS system equipped an FID detector with a DB-17 column $(30 \mathrm{~m} \times 0.32 \mathrm{~mm} \times 0.25 \mu \mathrm{m})$. The chromatographic conditions for detecting malathion were as follows: no split ratio; injection volume, $1 \mu \mathrm{l}$; injector program, $205{ }^{\circ} \mathrm{C}$ initially for $2.5 \mathrm{~min}$ and then increasing to $220^{\circ} \mathrm{C}$ for $2 \mathrm{~min}$ at $10{ }^{\circ} \mathrm{C} \mathrm{min}^{-1}$. 


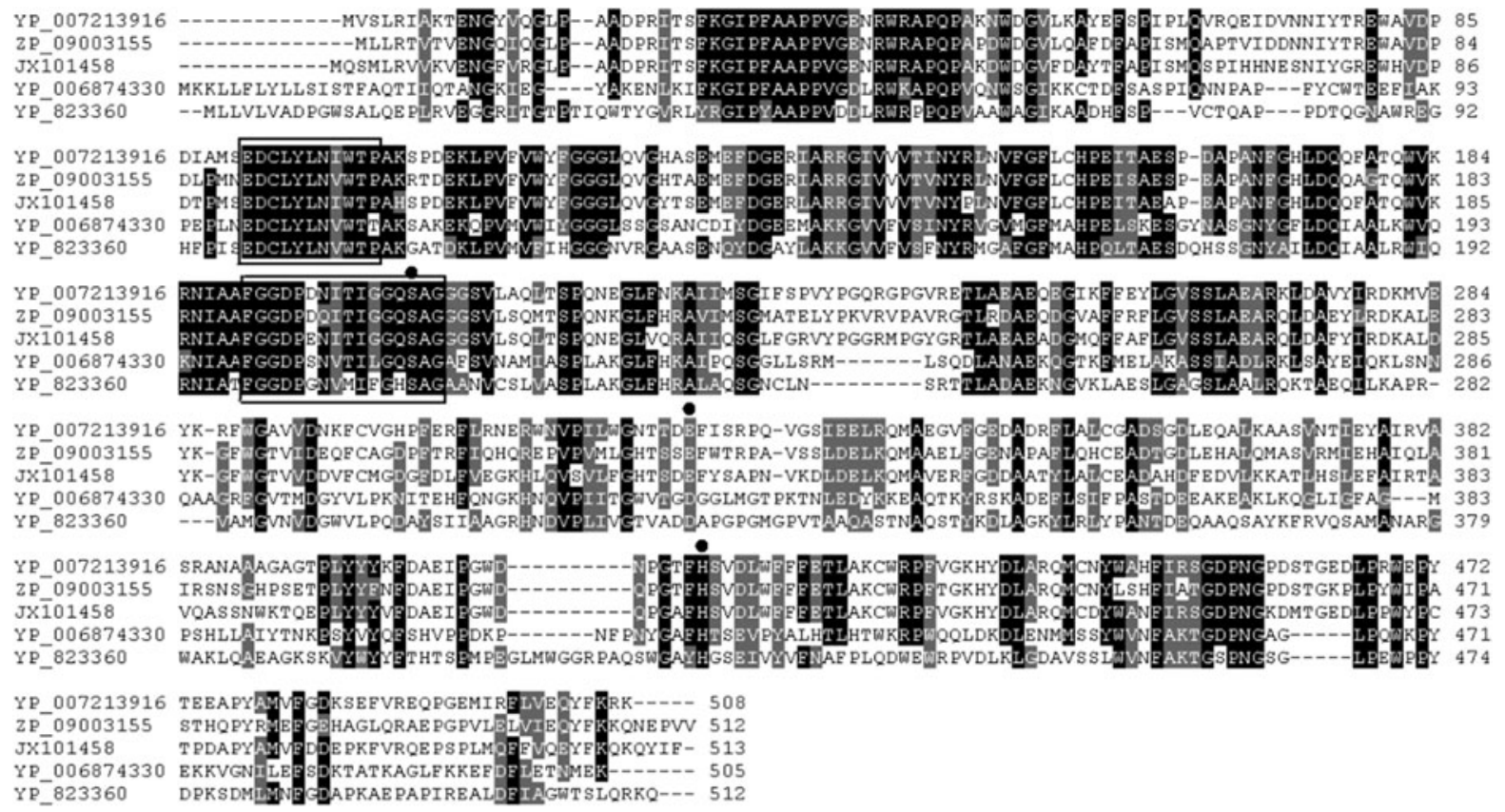

Fig. 2 Amino acid sequence alignment of D1CarE5 of type-B carboxylesterases. D1CarE5 showed 33-71\% sequence identity with type-B carboxylesterases from Candidatus Solibacter usitatus Ellin6076, Emticicia oligotrophica DSM 17448, Paenibacillus lactis 154, Thermobacillus composti KWC4, and D1CarE5 from a thermophilic Alicylobacillus tengchongensis

Fig. 3 SDS-PAGE analyses of D1CarE5. Lane $\mathrm{M}$, low-molecular weight markers; 1, D1CarE5 purified by $\mathrm{Ni}^{2+}-\mathrm{NTA}$ chelating affinity chromatography

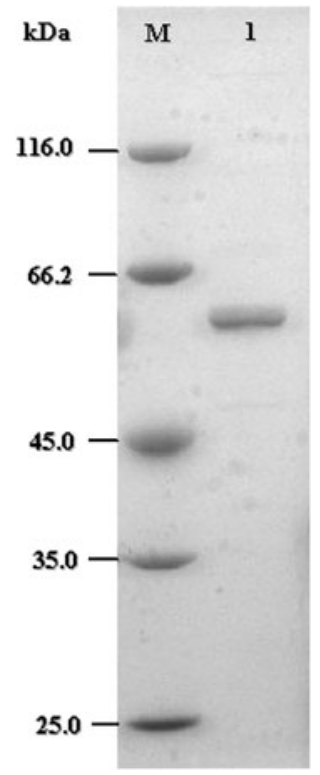

Different concentration gradients of a standard malathion solution were also injected to construct a standard curve. strain (GenBank accession number: JX101458; this study). The catalytic triad residues $\mathrm{S}$ (Ser), E (Glu)/D (Asp), H (His) are indicated by black dots. Both type-B carboxylesterase serine active site and type-B carboxylesterase signature 2 are underlined with black bars

\section{Results and discussion}

Sequence analyses

A 1,542 bp-long ORF that encoded for a 513 amino acid protein was found. This ORF had a predicted molecular weight (Mr) of $57.82 \mathrm{kDa}$ and $\mathrm{pI}$ of 4.52 . No signal sequence was found. The deduced amino acid sequence of D1CarE5 showed homology to type$\mathrm{B}$ carboxylesterases. Comparison of the derived amino acid sequence of D1CarE5 with those in the GenBank database showed that it had 33, 36, 68, and $71 \%$ identity to the putative type-B carboxylesterase from Candidatus Solibacter usitatus Ellin6076 (accession number: YP_823360), Emticicia oligotrophica DSM 17448 (accession number: YP_006874330), Paenibacillus lactis 154 (accession number: ZP_09003155), and Thermobacillus composti KWC4 (accession number: YP_007213916), respectively. Meanwhile, D1CarE5 shared $97 \%$ identity with the putative carboxylesterase from genome sequence of Alicyclobacillus hesperidum URH17-3-68 in GenBank that 

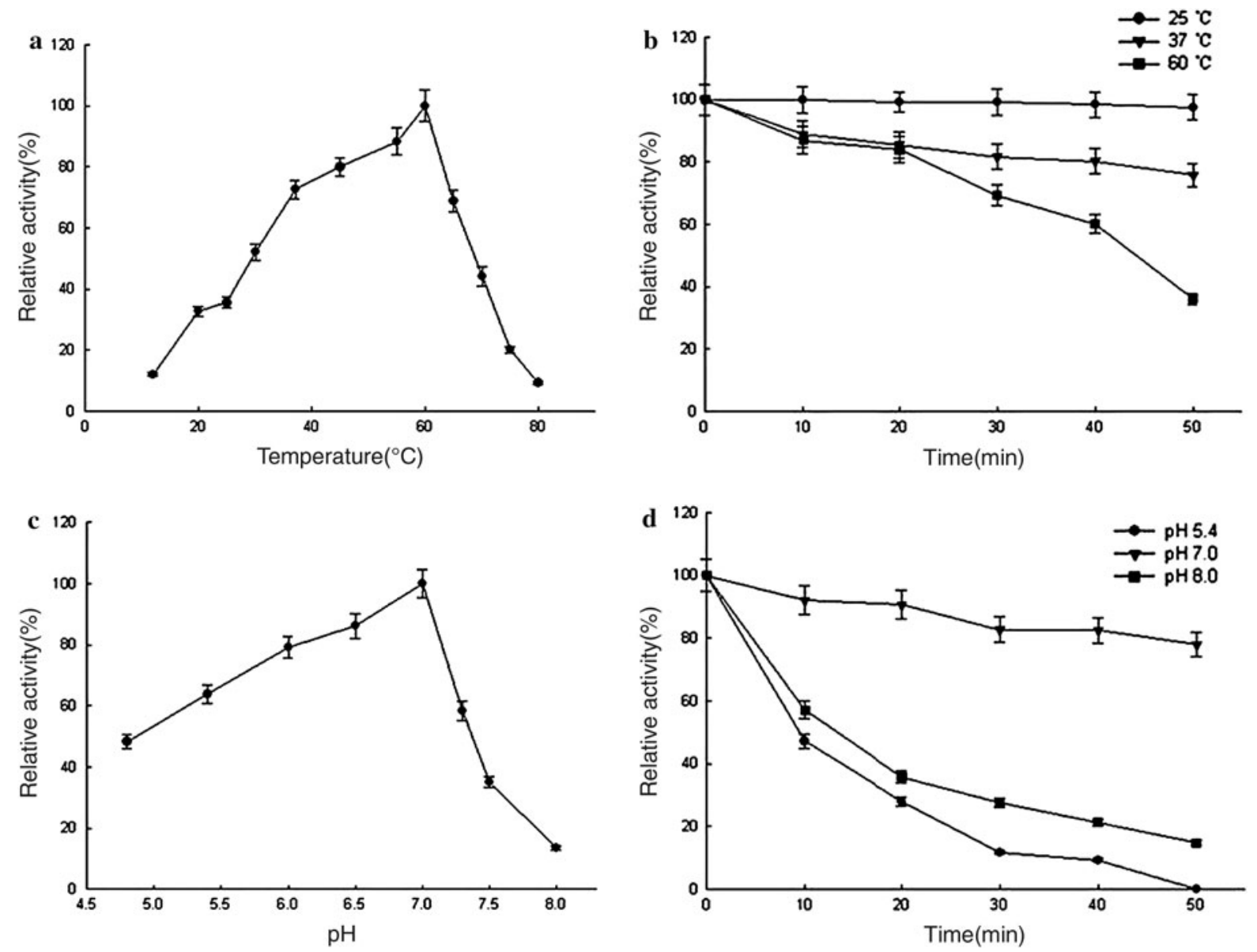

Fig. 4 The characterization of purified D1CarE5. a Effect of temperature on D1CarE5 activity measured in potassium phosphate buffer $(\mathrm{pH} 7)$ at $12-80{ }^{\circ} \mathrm{C}$. b Thermostability assay. Purified D1CarE5 was pre-incubated in potassium phosphate buffer $(\mathrm{pH} 7)$ at 25,37 , or $60{ }^{\circ} \mathrm{C}$. Aliquots were removed at specific time points for the measurement of residual activity at $37^{\circ} \mathrm{C}$. $\mathbf{c}$ Effect of $\mathrm{pH}$ on D1CarE5 activity. The enzyme activity

has not been reviewed and whose function is unknown (Wang et al. 2012; accession number: ZP_10953092). Comparison of the 16S rDNA sequences and phylogenetic analysis showed that the high identity can be attributed to the fact that the two strains belong to the same genus (Fig. 1). In addition, several microbial carboxylesterase genes have been cloned and expressed (Prim et al. 2001; Ewis et al. 2004), but the highest identity is only $34 \%$. Moreover, the association of these genes with malathion degradation has not been reported.

D1CarE5 was characterized by a type-B carboxylesterase signature 2 motif (EDCLYLNIWTP) at positions

was determined at $37{ }^{\circ} \mathrm{C}$ from $\mathrm{pH} 4.8$ to 8 . $\mathbf{d ~ p H}$ stability assay.

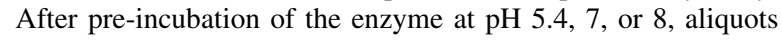
were removed at specific time points for the measurement of residual activity at $37^{\circ} \mathrm{C}$. The residual activity was expressed as a percentage of the activity measured at $37^{\circ} \mathrm{C}$ in potassium phosphate buffer ( $\mathrm{pH} 7)$. The error bars represent the mean \pm standard deviation $(n=3)$

92-102, another type-B carboxylesterase serine motif (FGGDPENITIGGQSAG) at positions 191-206, and notably the catalytic triad comprising Ser204, Glu325, and His415, which may form a charge-relay system (Gopalapillai et al. 2005). The sequence Gly-Xaa-SerXaa-Gly (Gly202-Gln203-Ser204-Ala205-Gly206) was conserved in all carboxylesterases (Fig. 2).

Expression and purification of D1CarE5

D1CarE5 gene cloned into pET28a (+) was used to transform E. coli BL21 (DE3) for expression and induced with $0.5 \mathrm{mM}$ IPTG at $20{ }^{\circ} \mathrm{C}$ for $20 \mathrm{~h}$. 


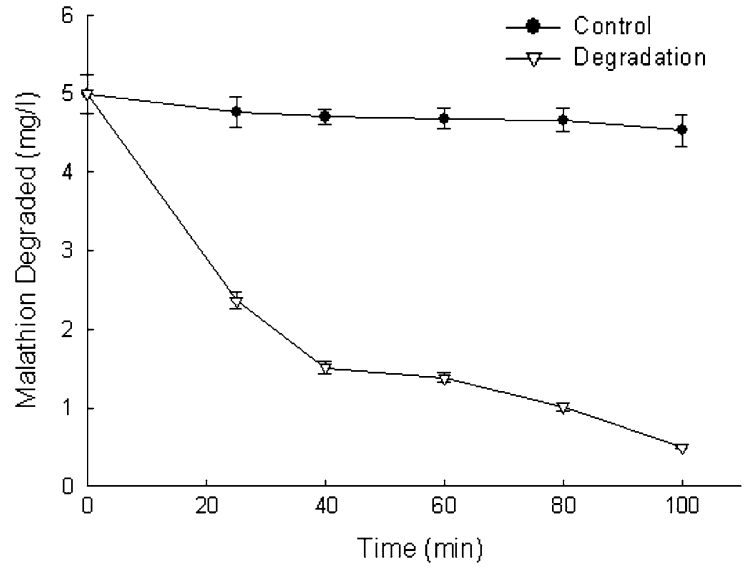

Fig. 5 Malathion degradation by purified D1CarE5. The reaction was performed in a $6 \mathrm{ml}$ graduated tube containing $1 \mathrm{U}$ enzyme, $5 \mathrm{mg}$ malathion $\mathrm{l}^{-1}$, and potassium phosphate buffer $(25 \mathrm{mM}, \mathrm{pH} 7)$ at $37{ }^{\circ} \mathrm{C}$. A malathion solution without enzyme served as a control. The error bars represent the mean $\pm \mathrm{SD}(n=3)$

The crude enzyme extracted from recombinant $E$. coli BL21 (DE3) cells was purified to electrophoretic homogeneity by $\mathrm{Ni}^{2+}$-NTA metal chelating affinity chromatography (Fig. 3). The purified enzyme with $\mathrm{His}_{6}$ migrated as a single band on SDS-PAGE with a molecular mass of $\sim 58 \mathrm{kDa}$, which was close to the calculated value of $57.82 \mathrm{kDa}$. The molecular mass of D1CarE5 differed from previous reports on pesticidedegrading enzymes, such as type-B carboxylesterase (53 kDa) from Bacillus sp. BP-7 (Prim et al. 2001), carboxylesterase $(60 \mathrm{kDa})$ from mouse liver microsomes (Stok et al. 2004), carboxylesterase B1 (65 kDa) from Culexpipiens (Lan et al. 2006), and carboxylesterase (31 kDa) from Sphingobium sp. strain JZ-1 (Wang et al. 2009).

\section{Enzyme characterization}

The optimum temperature for D1CarE5 activity was $60{ }^{\circ} \mathrm{C}$ (Fig. 4a). The enzyme was stable at $25^{\circ} \mathrm{C}$, and $>75 \%$ activity remained at $37^{\circ} \mathrm{C}$; by contrast, only $36 \%$ activity remained at $60{ }^{\circ} \mathrm{C}$ after $50 \mathrm{~min}$ (Fig. 4b). The purified enzyme was optimally active at pH 7 (Fig. 4c) and retained $>70 \%$ of its initial activity after incubation in $\mathrm{pH} 7$ buffer for $50 \mathrm{~min}$ at $37{ }^{\circ} \mathrm{C}$ (Fig. 4d); by contrast, the enzyme was not stable at $\mathrm{pH} 5.4$ or 8 . The activity of purified D1CarE5 was also determined in the presence of different metal ions and chemical reagents (data not shown). Enzyme activity was strongly inhibited by $1 \mathrm{mM} \mathrm{Zn}^{2+}, \mathrm{Hg}^{2+}$, $\mathrm{Cu}^{2+}, \mathrm{Ag}^{+}$, and $1 \%(\mathrm{w} / \mathrm{v})$ SDS, whereas $\mathrm{Pb}^{2+}$ and $\mathrm{Mg}^{2+}$ activated D1CarE5. The addition of $1 \%(\mathrm{v} / \mathrm{v})$ acetone and $1 \%(\mathrm{v} / \mathrm{v})$ ethanol had little effect on enzyme activity. The $K_{\mathrm{m}}$ for $\beta$-naphthyl acetate was

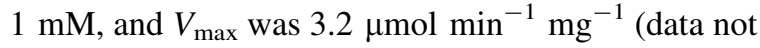
shown).

Degradation of pesticides by the recombinant D1CarE5

Malathion degradation by purified D1CarE5 is shown in Fig. 5. The recombinant D1CarE5 $(1 \mathrm{U} / \mathrm{ml})$ hydrolyzed $50 \%$ malathion $(5 \mathrm{mg} / \mathrm{l})$ within $25 \mathrm{~min}$ and $89 \%$ malathion within $100 \mathrm{~min}$. Although a number of bacteria with malathion hydrolase activity have been investigated (Foster and Bia 2004; Hashmi et al. 2004; Goda et al. 2010; Baljinder et al. 2012), recombinant carboxylesterases for malathion degradation have not been reported in Alicyclobacillus. The enzyme also shows stronger malathion degradation than carboxylesterase E4 from peach-potato aphid (Lan et al. 2005).

\section{Conclusions}

We cloned and expressed DICarE5 gene, purified the recombinant carboxylesterase and gained insight into the characteristics and malathion degradation by the recombinant D1CarE5. This is the first report on the heterologous expression of a carboxylesterase from Alicyclobacillus for malathion degradation. The culture supernatant of the bacterium was unable to degrade malathion and carboxylesterase activity was not detected (data not shown). The results indicated that the proposed strategic approach based on the microbial genome was an efficient and rapid method of finding functional carboxylesterases. Our work also showed that the recombinant enzyme has potential use for degrading environmental malathion. Further studies on the degradation of other pesticides by recombinant D1CarE5 and on the underlying mechanisms are underway.

Acknowledgments This work was supported by the National High Technology Research and Development Program of China (863 Program; No. 2008AA02Z202) and the National Natural Science Foundation of China (No. 31160229). 
Open Access This article is distributed under the terms of the Creative Commons Attribution License which permits any use, distribution, and reproduction in any medium, provided the original author(s) and the source are credited.

\section{References}

Baljinder S, Jagdeep K, Kashmir S (2012) Biodegradation of malathion by Brevibacillus sp. strain $\mathrm{KB} 2$ and Bacillus cereus strain PU. World J Microbiol Biotechnol 28:1133-1141

Barata C, Solayan A, Porte C (2004) Role of B-esterases in assessing toxicity of organophosphorus (chlorpyrifos, malathion) and carbamate (carbofuran) pesticides to Daphnia magna. Aquat Toxicol 66:125-139

Cao CW, Zhang J, Gao XW, Liang P, Guo HL (2008) Overexpression of carboxylesterase gene associated with organophosphorous insecticide resistance in cotton aphids, Aphis gossypii (Glover). Pestic Biochem Phys 90:175-180

Ewis HE, Abdelal AT, Lu CD (2004) Molecular cloning and characterization of two thermostable carboxyl esterases from Geobacillus stearothermophilus. Gene 329:187-195

Foster LJR, Bia H (2004) Microbial degradation of the organophosphate pesticide, Ethion. FEMS Microbiol Lett 240:49-53

Goda SK, Elsayed IE, Khodair TA, Elayed W, Mohamed ME (2010) Screening for and isolation and identification of malathion-degrading bacteria: cloning and sequencing a gene that potentially encodes the malathion-degrading enzyme, carboxylestrase in soil bacteria. Biodegradation 21:903-913

Gopalapillai R, Kadono-Okuda K, Okuda T (2005) Molecular cloning and analysis of a novel teratocyte-specific carboxylesterase from the parasitic wasp, Dinocampus coccinellae. Insect Biochem Mol Biol 35:1171-1180

Hashmi I, Khan MA, Kim JG (2004) Malathion degradation by Pseudomonas using activated sludge treatment system (Biosimulator). Biotechnology 3:82-89

Hung KS, Liu SM, Tzou WS, Lin FP, Pan CL, Fang TY, Sun KH, Tang SJ (2011) Characterization of a novel GH10 thermostable, halophilic xylanase from the marine bacterium Thermoanaerobacterium saccharolyticum NTOU1. Process Biochem 46:1257-1263

Inderjeet K, Mathur RP, Tandon SN, Dureja P (1997) Identification of metabolites of malathion in plant, water and soil by GC-MS. Biomed Chromatogr 11:352-355

Kumar R, Nagpure NS, Kushwaha B, Srivastava SK, Lakra WS (2010) Investigation of the genotoxicity of malathion to freshwater teleost fish Channa punctatus (Bloch) using the micronucleus test and comet assay. Arch Environ Contam Toxicol 58:123-130

Lan WS, Cong J, Jiang H, Jiang SR, Qiao CL (2005) Expression and characterization of carboxylesterase E4 gene from peach-potato aphid (Myzus persicae) for degradation of carbaryl and malathion. Biotechnol Lett 27:1141-1146

Lan WS, Gu JD, Zhang JL, Shen BC, Jiang H, Mulchandani A, Chen W, Qiao CL (2006) Coexpression of two detoxifying pesticide-degrading enzymes in a genetically engineered bacterium. Int Biodeter Biodegr 58:70-76

Leng XF, Qiao CL (1986) The biodegradation of the decis, acetofenate (7504) and DDT by the perfusion isolated rat cells (in Chinese). Chinese Sci Bull 19:1505-1508

Miller AD, Scott DF, Chacko TL, Maxwell DM, Schlager JJ, Lanclos KD (1999) Expression and partial purification of a recombinant secretory form of human liver carboxylesterase. Protein Expr Purif 17:16-25

Nishi K, Huang HZ, Kamita SG, Kim IH, Morisseau C, Hammock BD (2006) Characterization of pyrethroid hydrolysis by the human liver carboxylesterases hCE-1 and hCE-2. Arch Biochem Biophys 445:115-123

Prim N, Pastor FIJ, Diaz P (2001) Cloning and characterization of a bacterial cell-bound type B carboxylesterase from bacillus sp. BP-7. Curr Microbiol 42:237-240

Stok JE, Huang HZ, Jones PD, Wheelock CE, Morisseau C, Hammock BD (2004) Identification, expression, and purification of a pyrethroid-hydrolyzing carboxylesterase from mouse liver microsomes. J Biol Chem 279:29863-29869

Van AK (1962) A study of housefly esterases by means of a sensitive colorimetric method. J Insect Physiol 8:401-416

Vontas JG, Small GJ, Hemingway J (2000) Comparison of esterase gene amplification, gene expression and esterase activity in insecticide susceptible and resistant strains of the brown planthopper, Nilaparvata lugens (Stal). Insect Mol Biol 9:655-660

Wang BZ, Guo P, Huang BJ, Li L, He J, Li SP (2009) Cloning of a novel pyrethroid-hydrolyzing carboxylesterase gene from Sphingobium sp. strain JZ-1 and characterization of the gene product. Appl Environ Microbiol 75(17):5496-5500

Wang P, Li L, Chen XY, Jiang N, Liu GY, Chen L, Xu JY, Song H, Chen ZG, Ma YH (2012) Draft genome sequence of Alicyclobacillus hesperidum strain URH17-3-68. J Bacteriol 194(22):6348

Yoshii K, Tonogai Y, Katakawa J, Ueno H, Nakamuro K (2007a) Identification of carboxylesterase metabolites of residual malathion in wheat kernels using semi-micro radio liquid chromatography. J Health Sci 53:92-98

Yoshii K, Tonogai Y, Katakawa J, Ueno H, Nakamuro K (2007b) Kinetic analysis for hydrolysis of malathion by carboxylesterase in wheat kernels. J Health Sci 53:507-513

Zhang JL, Lan WS, Qiao CL, Jiang H (2004) Bioremediation of organophosphorus pesticides by surface-expressed carboxylesterase from mosquito on Escherichia coli. Biotechnol Prog 20:1567-1571

Zhou JP, Dong YY, Gao YJ, Tang XH, Li JJ, Yang YJ, Xu B, Xie ZR, Huang ZX (2012) Characterization of a family 3 polysaccharide lyase with broad temperature adaptability, thermo-alkali stability, and ethanol tolerance. Biotechnol Bioproc 17:729-738 